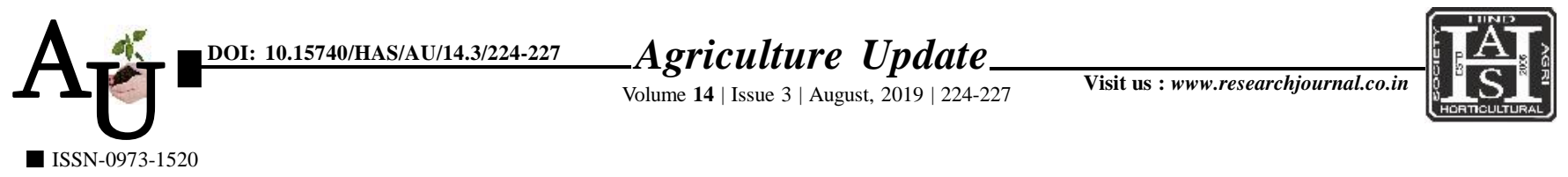

\title{
Research Article: Knowledge of Bt. cotton growers about management practices for control of pink bollworm
}

\author{
- S.B. Khodake, A.N. Deshmukh, V.B. Khodake and S.A. Deshmukh
}

Article Chronicle : Received : 04.06.2019;

Revised :

06.07.2019;

Accepted :

17.07.2019

KEY Words:

Knowledge, Bt cotton, Pink bollworm
SUMMARY : The present study on knowledge of Bt. cotton growers about management practices for control of pink bollworm was undertaken in Daryapur and Achalpur taluka of Amravati district. With sample size of the 80 respondents. The data were collected on personal, socio-economic, communicational and psychological characteristics of the Bt. cotton growers, knowledge about management practices for control of pink bollworm with the help of pre structured interview schedule. Finding reveled that majority 65.00 per cent of the respondents belonged to middle age group, high propotion of respondents 31.25 per cent were studied upto high school level, majority of respondent 37.50 per cent had small land holding ( 1.01 to $02.00 \mathrm{ha}$ ), majority 58.75 per cent respondents were having medium level farming experience, more than half of the respondents 77.50 per cent having annual income between Rs. 70,0001 to Rs. 2,90,000, majority of 60.00 per cent had occupied medium level of social participation, majority of 71.25 per cent of the respondents have medium level of extension contact, majority of the respondent 62.50 per cent had medium level of source of information, majority of the respondent 61.25 per cent of the respondents had medium level of achievement motivation, majority of the 66.25 per cent of the respondents had medium level of training received, majority of the 56.25 per cent found to be in the medium level of risk orientation. In case of knowledge of management practices for control of pink bollworm 67.50 per cent having medium level of knowledge. The variables education, farming experience, sources of information, training received and risk orientation are positively and highly significant with knowledge at 0.01 level of probability and the annual income, extension contact and achievement motivation are positively significant and age, land holding, social participation, were non-significantly correlated with knowledge of management practices for control of pink bollworm at 0.05 level of probability.

How to cite this article : Khodake, S.B., Deshmukh, A.N., Khodake, V.B. and Deshmukh, S.A. (2019). Knowledge of Bt cotton growers about management practices for control of pink bollworm. Agric. Update, 14(3): 224-227; DOI : 10.15740/HAS/AU/14.3/224-227. Copyright@ 2019: Hind Agri-Horticultural Society.
Author for correspondence :

\section{A.N. Deshmukh}

Department of Extension Education, Shri Shivaji

Agriculture College,

Amravati (M.S.) India

Email: abhaydeshmukh

$40 @$ rediffmail.com

See end of the article for

authors' affiliations 